\title{
Does Student Involvement in Practical Learning Strengthen Deeper Learning Competencies?
}

\author{
Agus Prianto* \\ Economic Education Department, STKIP PGRI Jombang, East Java, Indonesia \\ Umi Nur Qomariyah \\ Mathematic Education Department, STKIP PGRI Jombang, East Java, Indonesia \\ Firman \\ Civic Education Department, STKIP PGRI Jombang, East Java, Indonesia
}

\begin{abstract}
The rapidly changing world of work requires graduates to have the skills to adapt to new work environments. According to employers, the main weaknesses of vocational school graduates are their poor communication skills, inadequate problem-solving ability, and inability to learn how to learn. These shortcomings indicate the low level of students' deeper learning competencies (DLC). Learning activities at schools should strengthen students' DLC. This study describes students' involvement in practical learning, its impact, and the extent to which students' involvement in practical learning strengthens DLC. This research was conducted over four semesters at a referral vocational school in Jombang Regency, East Java, Indonesia. Descriptive analysis was used to uncover the data on students' involvement in practical learning and its various impacts, and students' DLC. It was found that the implementation of practical learning fosters students' involvement in schooling. The participation of students in practical learning affected the development of various learning behaviors and attitudes, which can strengthen DLC further. Project-based learning and school-based enterprise are two practical learning models that have a strong impact on the development of students' DLC. The effects of internship and learning through practice were in the strong category. Thus, learning activities in schools should be carried out by combining theoretical studies and practical learning. It is recommended that vocational schools strengthen their learning activities with project-based learning or school-based enterprise approaches.
\end{abstract}

Keywords: student involvement; practical learning; deeper learning competencies

\footnotetext{
*Corresponding author: Agus Prianto, agustkip@gmail.com
} 


\section{Introduction}

To face the rapidly changing world of work, vocational schools are under pressure to develop learning models that prepare students to be quality graduates. Vocational school graduates must master various competencies that are relevant to the skill-related qualifications demanded by the world of work. The suitability of the competencies, knowledge, and skills of graduates in relation to the qualifications demanded by the world of work will determine the readiness of graduates to enter the job market.

The rapidly changing world of work requires graduates to have the skills needed to adapt to a new work environment. To deal with rapid changes, AIR (American Institutes for Research) explains that it is important for educational institutions, including vocational schools, to prepare students to master knowledge (content), to strengthen skills for collaborating with others, and to apply knowledge in new situations (AIR, 2015). AIR suggests that students will have wider access to job opportunities, and be able to contribute optimally in the real-life environment if they have the skills needed to work in a team, and to conduct analysis by thinking critically in response to the challenges posed by the new era.

To respond to these challenges, educational institutions must ensure learning that strengthens students' competencies, so that they develop deep learning competencies (DLC) (Alliance for Excellent Education, 2011; Martinez, McGrath, \& Foster, 2016). Some developed countries in Europe created a framework to develop student competencies for engaging in deeper learning (STORIES Consortium, 2017). The Hewlett Foundation, which has studied the important role of education in building community civilization for more than 50 years, also emphasizes the importance of strengthening student competencies that relate to DLC (Hewlett Foundation, 2013).

To prepare graduates to compete in the future, certain educational institutions in the USA develop student learning with the aim of strengthening student competencies, so that students can be learners who master knowledge, apply knowledge to life, think critically and solve problems, work in teams, communicate effectively, direct themselves to continue learning, respond to the challenges posed by change, and think creatively and innovatively. These various competencies are acquired through deeper learning (Vander Ark \& Schneider, 2013; MacFarlane et al., 2017). The study conducted by MacFarlane et al. (2017) emphasizes the importance of deep learning for preparing prospective graduates to access various global economic opportunities in the 21st century. MacFarlane et al. (2017) explain that developing challenging learning practices that enable students to be more actively involved in learning activities, is important. They also advise teachers to carry out learning activities flexibly, so that students have the opportunity to engage in deeper learning. Previous studies have not specifically discussed the learning model that could be applied to develop student competencies that will enable students to be actively involved in deeper learning. 
Practical learning is one of the most important learning activities in vocational schools in Indonesia (Hadam et al., 2017). Through practical learning - activities in the real world - students are expected to develop the ability to apply the theory they learned in school. In addition, through practical learning, students are expected to gain experience on how they must do the job. Thus, practical learning should provide students with a deep understanding, not only because they know the theories, but because they can also put theory into practice in the real world (Billet, 2013).

This study examined the impacts of implementing four practical learning activities to develop DLC: 1) Practice in the workshop (learning through practice), 2) Internships, 3) Project-based learning (PBL), and 4) Practice of business activities at school (school-based enterprise (SBE)).

\subsection{Research Question}

This study aimed to answer the following research questions:

a) What is the nature of students' involvement in various practical learning activities that are carried out at schools?

b) What is the impact of involving students in various practical learning activities at schools?

c) Can the involvement of students in various learning activities, and the various impacts of this involvement, foster DLC?

\subsection{Purposes}

This study aimed to describe the involvement of students in four practical learning activities carried out at vocational schools, the impact of student involvement in the four practical learning activities, and the emergence of DLC in students after they were involved in the four practical learning activities.

\section{Student Involvement in Learning}

The intensity of student involvement in learning is related to student learning success (Prianto, 2016). Students who are actively involved in learning usually perform better academically and have more positive attitudes, and vice versa (Leonard, 2008; Smith et al., 2010). Studies have found that student involvement in learning can be known from various activities, among which student participation in learning, student participation in school activities, and student involvement in completing assignments (Ali \& Hasan, 2018); attention to, interest in, and seriousness of participation in learning (Yazzie-Mintz, 2010); motivation to learn, the desire of students to be involved in learning activities at school, school attendance and completing assignments given by the teacher (Salleh et al., 2013); and participation of students in school activities (Audas \& Willms, 2001).

Student involvement in learning comprises three aspects: 1) Behavioral engagement (such as student participation in activities), 2) Emotional engagement related to students' feelings during involvement in learning (such as feeling happy and enjoying activities), and 3) Cognitive engagement aspects related to student motivation, encouragement, and the ability to be an independent learner (Fredricks et al., 2004). These activities are confirmed by Briggs (2015), who states 
that involvement in learning reflects the level of students' interest in participating in learning activities, students' sincerity about interacting positively and cooperating with fellow students, and the strength of their motivation to carry out learning activities.

According to previous studies, several indicators of student involvement in learning can, thus, be identified: (1) Participation in learning, (2) Seriousness about carrying out learning tasks, (3) Attention and interest in learning activities, (4) Emotional involvement and feelings when carrying out learning activities, and

(5) Being encouraged to learn and explore learning tasks independently.

\section{Practical Learning at Vocational Schools}

Certain practical learning activities are commonly carried out at vocational schools in Indonesia, and these activities will be discussed next.

\subsection{Learning through Practice}

Learning through practice is a learning activity that requires students to apply theory through practical learning activities that are carried out in workshops. A workshop is a place where practical activities are carried out. Through the activities in workshops, students gain a deeper understanding of the theories learned in class. In other words, practical learning in the workshop will provide opportunities for students to apply theory (Roesman, 1988). Through engaging in these workshop activities, theoretical knowledge and practical activities become one joint learning activity (Wren \& Wren, 2009; Clapton \& Cree, 2004). Practical learning deepens students' understanding of theory, and enables them to develop the theory further. A deep understanding is likely to develop students' interest in exploring theory further.

\subsection{Internship}

Law No. 13, 2003 of the Republic of Indonesia, concerning employment, explains that apprenticeship is part of a job training system that is applied, in an integrated manner, between work education institutions and real workplaces under the guidance and supervision of instructors (experienced personnel in the process of producing goods and services). Internship activities at vocational schools in Indonesia are called industrial work practices.

Internship activities are educational training and learning activities carried out in the business and industrial world, in fields relevant to the competencies and fields of knowledge of the students. Through internship activities, students work to acquire new knowledge and skills that are not obtained through learning activities at school; doing so also provides opportunities for students to explore various types of careers, and develop their future careers. Internships are practical learning activities that provide students with real-world experiences. Internships have long been recognized as activities that can develop students' work readiness (Eraut, 2004).

Quality internship activities are characterized by intensive student involvement in work activities related to their fields of knowledge and competence - not only 
involvement in administrative activities. Internship activities must provide a clear description of the types of activities that must be carried out, so that students will gain work experience. Internship activities can also become the medium for students to learn about organizations, organizational culture, and the various work activities in an organization. Internship activities at vocational schools in Indonesia are carried out for 3-6 months. Deissinger and Hellwig (2005) explain that, through internships, students can develop work values and attitudes, develop careers, and develop professional attitudes that will be needed when they enter the workforce.

\subsection{Project-Based Learning}

PBL is intended to teach students, when they create projects or activities to solve existing problems, to relate what they have learned to the problems in their environment. PBL is also intended to train students by developing their potential to become innovative, creative individuals, and to enable them to work in a work team. Students learn and practice by observing various opportunities and problems in their environments, and then develop products or services that can be offered to the community. Through PBL, students are trained to work in a team, and to make in-depth observations about various problems that exist in the environment. The students and the team then develop a project or activity to solve the problems that were identified.

Generally, PBL comprises a number of steps, such as planning, creating, and processing. Teachers, who implement the PBL approach, could follow the following steps: (1) Start with the essential question, (2) Design a plan for the project, (3) Create a schedule, (4) Monitor the students and the progress of the project, (5) Assess the outcome, and (6) Evaluate the experiences (Hung et al., 2004). Sumarni (2015) explains the various advantages of implementing PBL, including (1) Increasing students' motivation to learn, (2) Improving students' academic achievement, (3) Improving collaboration skills, (4) Improving communication skills, (5) Improving students' skills to manage learning resources, (6) Creating a pleasant learning atmosphere, (7) Strengthening various positive attitudes of students, (8) Improving student creativity, (9) Strengthening problem-solving skills, and (10) Strengthening resource management skills.

\subsection{School-Based Enterprises}

An SBE involves practical learning during which students produce goods and services to sell to others (Stern et al., 1994). In some vocational schools, SBE practical learning is done by assigning students to produce goods and services during entrepreneurship lesson hours, then selling the products in schools. The goal is to teach students to be productive individuals. In addition, through this activity, students become accustomed to selling manufactured goods and services, and they gain real-world experience in identifying market opportunities, determining the right marketing strategy, and strengthening the habit of transacting in business activities.

Gugerty et al. (2008) and Walker and Shinn (2002) define SBE as business activities carried out by students, which can provide economic and social benefits, and strengthen educational aspects for the students themselves, the school, and the 
community. This activity is designed to familiarize students with being responsible individuals who are accustomed to undertaking activities based on reward and punishment values, to foster self-confidence in realizing personal targets, and to strengthen personal independence.

Gamache and Knab (2018) describe various skills that can be developed through SBE activities, including (1) Skills used in managing a business, (2) Analytical thinking skills, (3) Communication and social skills, and (4) Personal skills, in addition to strengthening academic achievement.

Based on the explanation of the four practical learning activities described above, it can be concluded that the involvement of students in practical learning has a positive impact, including improvement of (1) Creative, analytical, innovative and problem-solving academic skills, (2) Practical skills, (3) Independence (learning how to learn), (4) Values and work attitudes, (5) Understanding of careers, (6) Collaboration skills, and (7) Communication skills.

\section{The Importance of Strengthening Deeper Learning Competencies}

Vocational schools aim to develop skills, provide hands-on experience in a particular field of work, provide a way to solve problems in the workplace and prepare graduates for careers in specific occupational fields. The Commission on Adult Vocational Teaching and Learning (2013) explains that the educational activities implemented at vocational schools should be compatible with what is taught in school, and what is required by the world of work.

To enable students to face the challenges of the world of work in the future, learning activities at vocational schools should be aimed at developing students' DLC (AIR, 2015). DLC will enable students to build an in-depth understanding of the knowledge they are studying, while, at the same time, applying the knowledge in real life. Deeper learning will also enable students to develop the ability to work in teams, access career opportunities, and develop critical thinking skills to solve problems encountered in the real world.

Deep learning is a learning skill that enables students to understand knowledge in depth, to utilize what they have learned, and to apply it as needed, both during the study at school, and during application in the real world. The Hewlett Foundation (2013) defines deeper learning as a set of competencies that students must master in order to build a deep understanding of the knowledge they acquire, and to apply it in the workplace. Thus, deeper learning enables students to develop cognitive, interpersonal, and intrapersonal skills. Through deeper learning, students are not just memorizing facts, concepts, techniques, and procedures; instead, they will know the underlying principles, and understand when and how they can be applied in new situations.

A report, entitled Deeper Learning Improving Students' Outcomes for College, Career, and Civic Life (AIR, 2015), reveals the benefits that will be obtained when students develop DLC, including (1) Cognitive aspects: having a deep understanding of what is learned and being able to apply it in the real world, being able to develop 
critical thinking and problem-solving skills, and an increase in creative behavior; (2) Interpersonal aspects: better communication skills and collaboration skills; and (3) Intrapersonal aspects: ability to self-teach, deep involvement in learning activities, strong learning motivation, belief in one's own abilities, being able to direct oneself to be a productive person, and persistence.

The Hewlett Foundation (2013), Trilling (2010), and Pellegrino and Hilton (2012) reveal that deep learning will strengthen six interrelated competencies. DLC is a prerequisite for success, not only at school, but also at university. It is believed that students who have the following six competencies will achieve high achievements, both during their studies and later, after developing their careers in the workplace: (1) Mastering core knowledge in depth, (2) Critical thinking skills and solving complex problems, (3) Collaboration skills, (4) Effective communication skills, (5) Self-learning skills, and (6) A rational academic mindset.

Several studies on the importance of student involvement in various practical learning activities at vocational schools in Indonesia show that the impact of practical learning and DLC is that more intense student involvement in practical learning can strengthen students' DLC.

\section{Research Method}

This research was done at three vocational schools in Jombang Regency, East Java, with the status of reference schools, namely SMK 1 Jombang, SMK 2 Jombang, and SMK PGRI 1 Jombang. The results of the research conducted at the three schools can be used as a reference point by similar schools to optimize the implementation of practical learning. The research sample was determined using purposive sampling (Scheaffer et al., 1995); 20 students were sampled at each school. This research was conducted for four semesters, with the same respondents, that is, 20 students at each school. Thus, the total number of respondents in this study was 60 students.

In semester 1, students participated in learning through practice; In semester 2, students participated in SBE. In semester 3, students participated in PBL, and in semester 4, students participated in internships. After completing each of the four practice-based learning activities, the supervising teacher, at the end of each semester, assessed the intensity of students' involvement in practical learning. The impact of practical learning and the students' DLC were measured using a questionnaire that had been developed by the researchers (see Appendix).

This study used quantitative descriptive analysis techniques (Narbuko \& Achmadi, 2015; Sukmadinata, 2017; Sugiyono, 2018; Arikunto, 2019) to describe three variables, namely: 1) The level of student involvement in each of four practical learning activities, 2) The impact of practical learning, and 3) DLC.

Student involvement in practical learning was measured using five indicators, namely (1) Participation in learning, (2) Seriousness in carrying out learning tasks, (3) Attention to and interest in learning activities, (4) Emotions and feelings when 
carrying out learning activities, and (5) Students being encouraged to study and explore learning tasks independently.

The impact of practical learning is identified from the emergence of various indicators, namely (1) Academic skills (creative thinking skills, analytical, innovative, and problem-solving skills), (2) Practical skills, (3) Self-learning skills (learning how to learn), (4) Strengthened work values and attitudes, (5) Career understanding, (6) Work readiness, and (7) Strengthened collaboration and communication skills.

Meanwhile, DLC was measured using six indicators, that is, (1) Mastering core knowledge in depth, (2) Critical thinking skills and solving complex problems, (3) Collaborating skills, (4) Effective communication skills, (5) Self-learning skills, and (6) Developing a rational academic mindset.

Data collection was carried out using a 7-scale semantic differential scale questionnaire (lowest score 1, highest score 7) (Sugiyono, 2018). Questionnaires about student involvement in practical learning, the impact of practical learning, and questionnaires on DLC were developed by researchers using the indicators proposed in this study. The categories of student involvement in practical learning, practical learning outcomes, and DLC are as shown in Table 1.

Table 1: Categories of learning engagement, practical learning outcome, and DLC

\begin{tabular}{|l|l|c|l|}
\hline Score & Description & Score & Description \\
\hline $1.00-1.85$ & Very low & $4.43-5.28$ & Slightly high \\
\hline $1.86-2.71$ & Low & $5.29-6.14$ & High \\
\hline $2.72-3.56$ & Slightly low & $6.15-7.00$ & Very high \\
\hline $3.57-4.42$ & Moderate & & \\
\hline
\end{tabular}

Questionnaires for data collection were developed by researchers based on indicators of learning engagement, the impact of engagement on practical learning, and deeper learning competencies. Before being used as a means to assess students, the research questionnaire was first tested for validity and reliability. Furthermore, a questionnaire statement is set for each indicator with the best level of validity and reliability. The results of the validity and reliability test of the questionnaire are presented in Table 2.

Table 2: Validity and reliability

\begin{tabular}{|c|c|c|c|c|}
\hline Variable & Indicator & Statement & Validity & Reliability \\
\hline \multirow{3}{*}{$\begin{array}{l}\text { Student } \\
\text { engagement } \\
\text { in practical } \\
\text { learning }\end{array}$} & $\begin{array}{l}\text { Participation in } \\
\text { learning }\end{array}$ & $\begin{array}{l}\text { Students actively participate } \\
\text { in practical learning }\end{array}$ & 0.78 & \multirow{3}{*}{0.79} \\
\hline & $\begin{array}{l}\text { The seriousness } \\
\text { of students in } \\
\text { carrying out the } \\
\text { task }\end{array}$ & $\begin{array}{l}\text { Students are serious about } \\
\text { carrying out practical } \\
\text { learning tasks }\end{array}$ & 0.82 & \\
\hline & $\begin{array}{l}\text { Students' } \\
\text { attention to and }\end{array}$ & $\begin{array}{l}\text { Students show high interest } \\
\text { in practical learning }\end{array}$ & 0.77 & \\
\hline
\end{tabular}




\begin{tabular}{|c|c|c|c|c|}
\hline Variable & Indicator & Statement & Validity & Reliability \\
\hline & $\begin{array}{l}\text { interest in } \\
\text { practical } \\
\text { learning }\end{array}$ & & & \\
\hline & $\begin{array}{l}\text { Students' } \\
\text { emotions and } \\
\text { feelings as } \\
\text { expressed when } \\
\text { carrying out } \\
\text { practical } \\
\text { learning }\end{array}$ & $\begin{array}{l}\text { Students show a happy and } \\
\text { enthusiastic attitude when } \\
\text { carrying out practical } \\
\text { learning }\end{array}$ & 0.81 & \\
\hline & $\begin{array}{l}\text { Students' } \\
\text { independence in } \\
\text { learning }\end{array}$ & $\begin{array}{l}\text { Students show independence } \\
\text { to learn more what has been } \\
\text { learned in practical learning }\end{array}$ & 0.83 & \\
\hline \multirow{8}{*}{$\begin{array}{l}\text { Practical } \\
\text { learning } \\
\text { outcome }\end{array}$} & Academic skills & $\begin{array}{l}\text { Students are able to think } \\
\text { creatively, innovatively, and } \\
\text { analytically to solve complex } \\
\text { problems }\end{array}$ & 0.79 & \multirow{8}{*}{0.79} \\
\hline & Practical skills & $\begin{array}{l}\text { Students are able to apply } \\
\text { theory to carry out certain } \\
\text { tasks }\end{array}$ & 0.81 & \\
\hline & $\begin{array}{l}\text { Learning how to } \\
\text { learn }\end{array}$ & $\begin{array}{l}\text { Students are able to direct } \\
\text { themselves to explore the } \\
\text { subject matter that has been } \\
\text { studied at school }\end{array}$ & 0.81 & \\
\hline & Work attitudes & $\begin{array}{l}\text { Students show positive work } \\
\text { behavior and attitudes }\end{array}$ & 0.78 & \\
\hline & $\begin{array}{l}\text { Career } \\
\text { orientation }\end{array}$ & $\begin{array}{l}\text { Students understand the } \\
\text { careers they will pursue after } \\
\text { graduation }\end{array}$ & 0.79 & \\
\hline & Work readiness & $\begin{array}{l}\text { Students demonstrate work } \\
\text { readiness }\end{array}$ & 0.82 & \\
\hline & Collaboration & $\begin{array}{l}\text { Students are able to work in } \\
\text { teams }\end{array}$ & 0.80 & \\
\hline & Communication & $\begin{array}{l}\text { Students are able to } \\
\text { communicate well, both } \\
\text { orally and in writing, on } \\
\text { various activities that have } \\
\text { been carried out in practical } \\
\text { learning }\end{array}$ & 0.77 & \\
\hline \multirow{3}{*}{$\begin{array}{l}\text { Deeper } \\
\text { learning } \\
\text { competencies }\end{array}$} & $\begin{array}{l}\text { Mastery of core } \\
\text { academic, } \\
\text { content }\end{array}$ & $\begin{array}{l}\text { Students are able to apply } \\
\text { facts, processes, and theories } \\
\text { to real-world situations }\end{array}$ & 0.83 & \multirow{3}{*}{0.83} \\
\hline & $\begin{array}{l}\text { Think critically, } \\
\text { solve complex } \\
\text { problems }\end{array}$ & $\begin{array}{l}\text { Students are able to apply } \\
\text { tools and techniques for } \\
\text { certain activities to collect the } \\
\text { necessary data and } \\
\text { information }\end{array}$ & 0.84 & \\
\hline & $\begin{array}{l}\text { Work } \\
\text { collaboratively }\end{array}$ & $\begin{array}{l}\text { Students are able to } \\
\text { collaborate with others to } \\
\text { complete assignments and } \\
\text { solve problems successfully }\end{array}$ & 0.82 & \\
\hline
\end{tabular}




\begin{tabular}{|c|c|c|c|c|}
\hline Variable & Indicator & Statement & Validity & Reliability \\
\hline & $\begin{array}{l}\text { Communicate } \\
\text { effectively }\end{array}$ & $\begin{array}{l}\text { Students are able to } \\
\text { communicate complex } \\
\text { concepts to others in both } \\
\text { written and oral } \\
\text { presentations }\end{array}$ & 0.83 & \\
\hline & $\begin{array}{l}\text { Learn how to } \\
\text { learn }\end{array}$ & $\begin{array}{l}\text { Students are regularly able to } \\
\text { reflect on their learning } \\
\text { experiences and apply their } \\
\text { understanding to subsequent } \\
\text { situations }\end{array}$ & 0.82 & \\
\hline & $\begin{array}{l}\text { Academic } \\
\text { mindset }\end{array}$ & $\begin{array}{l}\text { Students readily become } \\
\text { involved in developing } \\
\text { meaning and constructing } \\
\text { understanding through } \\
\text { interaction with peers }\end{array}$ & 0.84 & \\
\hline
\end{tabular}

\section{Results}

\subsection{Students' Involvement in Practical Learning Activities}

This study investigated the involvement of students in four practical learning activities as measured by five indicators, namely participation in learning, the seriousness of students in carrying out the task, students' attention to and interest in practical learning, emotions and feelings students express when carrying out practical learning, and students' independence in learning. This study found that PBL can foster student engagement at a very high level. Meanwhile, SBE, practice, and internship can foster student learning involvement at a high level. Overall, all four practical learning activities can foster student involvement in practical learning at a high level (see Table 3 and Figure 1).

Table 3: Student involvement in practical learning

\begin{tabular}{|l|l|l|l|l|l|l|l|l|l|l|}
\hline $\begin{array}{l}\text { Involvement } \\
\text { indicator }\end{array}$ & \multicolumn{2}{|c|}{ Practice } & \multicolumn{2}{|c|}{ Internship } & \multicolumn{2}{|c|}{ PBL } & \multicolumn{2}{c|}{ SBE } & \multicolumn{2}{c|}{ Mean } \\
\hline Participation & 5.5 & High & 5.4 & High & 6.7 & $\begin{array}{l}\text { Very } \\
\text { high }\end{array}$ & 5.9 & High & 5.88 & High \\
\hline Assignment & 5 & $\begin{array}{l}\text { Slightly } \\
\text { high }\end{array}$ & 5.6 & High & 6.3 & $\begin{array}{l}\text { Very } \\
\text { high }\end{array}$ & 5.8 & High & 5.68 & High \\
\hline Attention & 5.1 & $\begin{array}{l}\text { Slightly } \\
\text { high }\end{array}$ & 5.5 & High & 6.5 & $\begin{array}{l}\text { Very } \\
\text { high }\end{array}$ & 5.6 & High & 5.68 & High \\
\hline Interest & 5.15 & $\begin{array}{l}\text { Slightly } \\
\text { high }\end{array}$ & 5.55 & High & 6.7 & $\begin{array}{l}\text { Very } \\
\text { high }\end{array}$ & 5.8 & High & 5.8 & High \\
\hline Emotional & 4.9 & $\begin{array}{l}\text { Slightly } \\
\text { high }\end{array}$ & 5.4 & High & 6.6 & $\begin{array}{l}\text { Very } \\
\text { high }\end{array}$ & 5.9 & High & 5.7 & High \\
\hline Autonomy & 4.7 & $\begin{array}{l}\text { Slightly } \\
\text { high }\end{array}$ & 5.7 & High & 6.8 & $\begin{array}{l}\text { Very } \\
\text { high }\end{array}$ & 6.2 & $\begin{array}{l}\text { Very } \\
\text { high }\end{array}$ & 5.85 & High \\
\hline Average & 5.06 & $\begin{array}{l}\text { Slightly } \\
\text { high }\end{array}$ & 5.53 & High & 6.6 & $\begin{array}{l}\text { Very } \\
\text { high }\end{array}$ & 5.87 & High & 5.76 & High \\
\hline
\end{tabular}




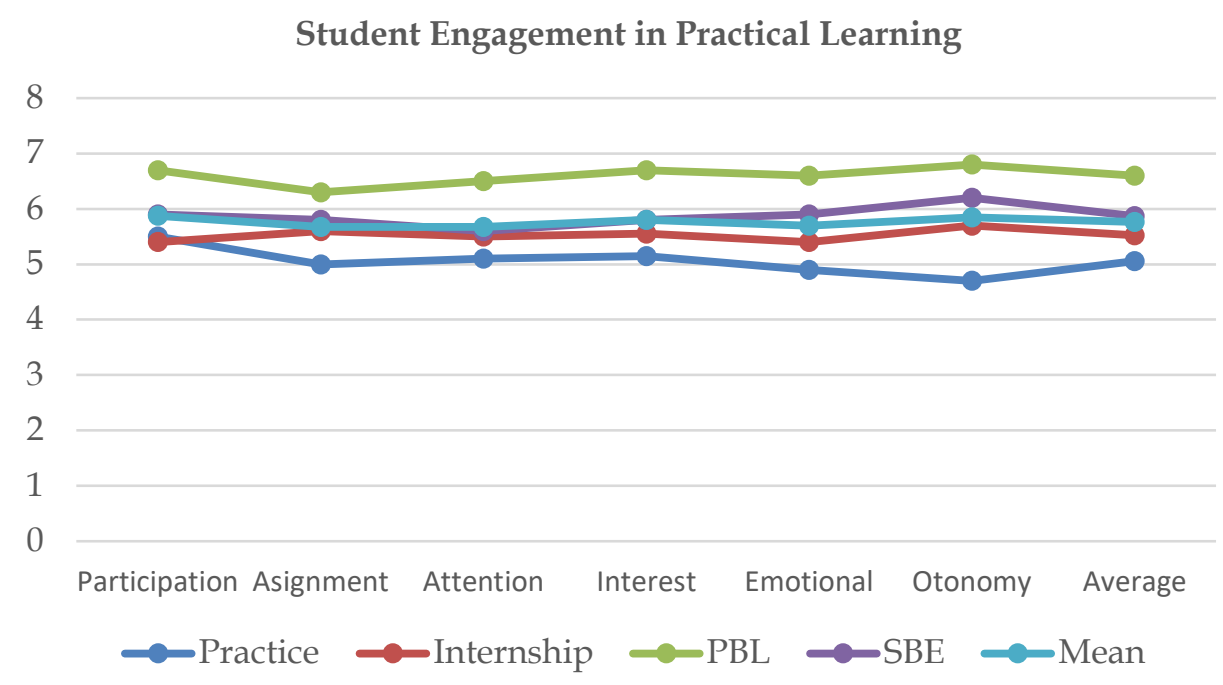

Figure 1: Student engagement based on practical learning model

\subsection{The Impact of Practical Learning}

This research revealed that three practical learning activities have powerful learning impacts: PBL, SBE, and internship (from the highest to the lowest). Meanwhile, learning through practice produces a learning impact in the slightly high category. Indicators of practical learning impact were academic skills, practical skills, autonomy, work attitudes, career orientation, collaborative skills, and communication skills. PBL is a practical learning activity, and had the highest learning impact. Except for the career orientation indicator, the other six indicators have an impact score close to the maximum score (see Table 4 and Figure 2).

This research reveals that another impact of practical learning is the improvement of various skills needed in the world of work of the future. These skills are academic skills and practical skills, which include creative thinking skills, innovation, and complex problem-solving, which will be needed by graduates when they enter a world of work that is constantly changing. Likewise, independence, work attitude, career orientation, collaboration and communication skills are skills that will strengthen students' readiness to enter the world of work.

Table 4: The outcomes of practical learning

\begin{tabular}{|l|l|l|l|l|l|l|l|l|l|l|}
\hline \multicolumn{1}{|c|}{ Outcome } & \multicolumn{2}{|c|}{ Practice } & \multicolumn{2}{c|}{ Internship } & \multicolumn{2}{|c|}{ PBL } & \multicolumn{2}{|c|}{ SBE } & \multicolumn{2}{c|}{ Mean } \\
\hline Academic skills & 5.5 & High & 6.2 & $\begin{array}{c}\text { Very } \\
\text { high }\end{array}$ & 6.6 & $\begin{array}{c}\text { Very } \\
\text { high }\end{array}$ & 6.2 & $\begin{array}{c}\text { Very } \\
\text { high }\end{array}$ & 6.13 & High \\
\hline Practical skills & 5.2 & $\begin{array}{l}\text { Slightly } \\
\text { high }\end{array}$ & 6.4 & $\begin{array}{c}\text { Very } \\
\text { high }\end{array}$ & 6.7 & $\begin{array}{c}\text { Very } \\
\text { high }\end{array}$ & 6.4 & $\begin{array}{c}\text { Very } \\
\text { high }\end{array}$ & 6.18 & $\begin{array}{c}\text { Very } \\
\text { high }\end{array}$ \\
\hline Autonomy & 5.1 & $\begin{array}{l}\text { Slightly } \\
\text { high }\end{array}$ & 6.3 & $\begin{array}{c}\text { Very } \\
\text { high }\end{array}$ & 6.8 & $\begin{array}{c}\text { Very } \\
\text { high }\end{array}$ & 6.3 & $\begin{array}{c}\text { Very } \\
\text { high }\end{array}$ & 6.13 & High \\
\hline Work attitudes & 4.7 & $\begin{array}{l}\text { Slightly } \\
\text { high }\end{array}$ & 6.2 & $\begin{array}{c}\text { Very } \\
\text { high }\end{array}$ & 6.7 & $\begin{array}{c}\text { Very } \\
\text { high }\end{array}$ & 6.3 & $\begin{array}{c}\text { Very } \\
\text { high }\end{array}$ & 6.08 & High \\
\hline
\end{tabular}




\begin{tabular}{|l|l|l|l|l|l|l|l|l|l|l|}
\hline Career & 4.5 & $\begin{array}{l}\text { Slightly } \\
\text { high }\end{array}$ & 6.2 & $\begin{array}{l}\text { Very } \\
\text { high }\end{array}$ & 6.4 & $\begin{array}{l}\text { Very } \\
\text { high }\end{array}$ & 6.5 & $\begin{array}{c}\text { Very } \\
\text { high }\end{array}$ & 5.85 & High \\
\hline $\begin{array}{l}\text { Collaboration } \\
\text { skills }\end{array}$ & 4.3 & Moderate & 6.4 & $\begin{array}{c}\text { Very } \\
\text { high }\end{array}$ & 6.9 & $\begin{array}{l}\text { Very } \\
\text { high }\end{array}$ & 6.6 & $\begin{array}{c}\text { Very } \\
\text { high }\end{array}$ & 6.05 & High \\
\hline $\begin{array}{l}\text { Communication } \\
\text { skills }\end{array}$ & 4.2 & Moderate & 6.5 & $\begin{array}{c}\text { Very } \\
\text { high }\end{array}$ & 6.8 & $\begin{array}{l}\text { Very } \\
\text { high }\end{array}$ & 6.8 & $\begin{array}{c}\text { Very } \\
\text { high }\end{array}$ & 6.08 & High \\
\hline Average & $\begin{array}{l}4.7 \\
8\end{array}$ & $\begin{array}{l}\text { Slightly } \\
\text { high }\end{array}$ & $\begin{array}{l}6.3 \\
4\end{array}$ & $\begin{array}{l}\text { Very } \\
\text { high }\end{array}$ & 6.7 & $\begin{array}{l}\text { Very } \\
\text { high }\end{array}$ & 6.44 & $\begin{array}{l}\text { Very } \\
\text { high }\end{array}$ & 6.07 & High \\
\hline
\end{tabular}

The Impact of Practical Learning

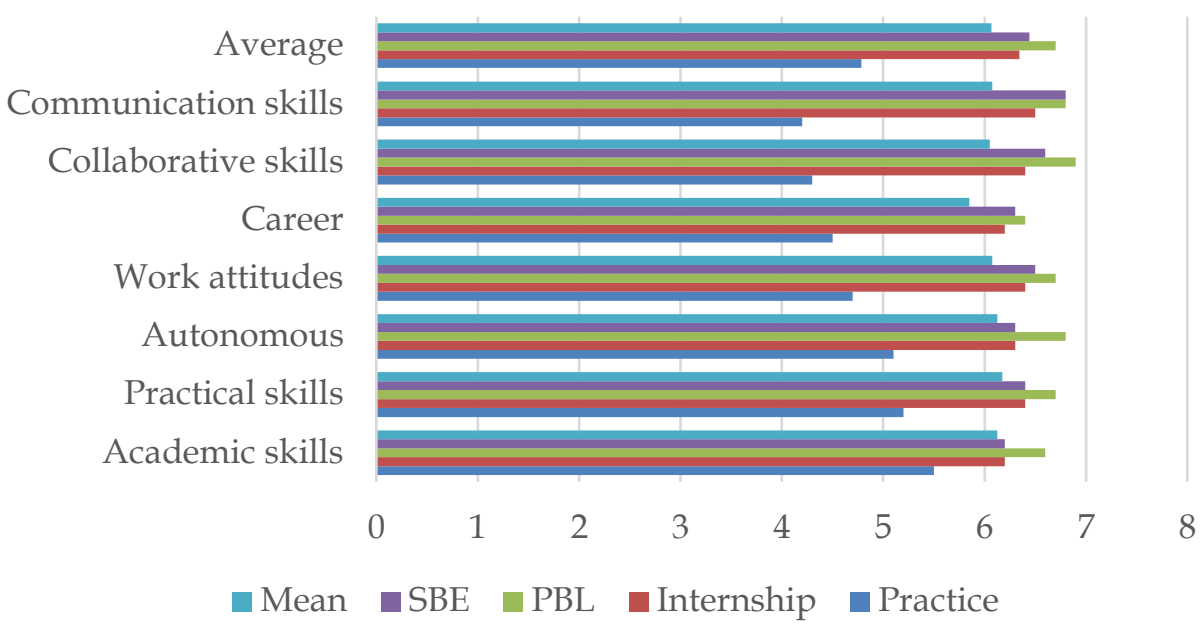

Figure 2: The impact of learning based on practical learning model

\subsection{Students' Deeper Learning Competencies (DLC)}

This research reveals that the intensity of student involvement in practical learning can sharpen students' understanding of the basic knowledge that they have acquired, and help them to apply it in the real world. The involvement of students in practical learning also challenges students to apply the knowledge they have acquired, and to explore, discover knowledge and develop new skills that are needed in the real world.

This research proves that the involvement of students in four learning activities, namely, learning through practice, internship, project-based learning, and schoolbased enterprises, can strengthen deep learning skills. Students' involvement is marked by the emergence of student learning behaviors such as the following: (1) Students can apply various theories to the real world. This shows that student involvement in practical learning can strengthen their understanding of the subject matter (mastering core academic content). (2) Students can use various tools, understand work procedures, and collect data and information needed for job analysis. Students are educated to apply the tools and techniques obtained from the core subjects to formulate and solve problems. (3) Students can collaborate with others to complete work activities and solve various problems that occur in the workplace. Students can work together with peers to identify problems and create solutions to solve various academic, social, vocational, and 
personal challenges. (4) Students can communicate about various activities to others, both in writing and verbally. (5) Students are accustomed to doing reflection on various learning activities that have been carried out, and enrich the learning experience that will be used to carry out various further activities. Thus, students are accustomed to monitoring their learning progress and directing themselves to develop further. (6) Students are accustomed to building an understanding of what they have experienced together with their peers. Students develop positive attitudes about themselves as independent learners, and increase their academic persistence, and this encourages them to engage in productive academic behavior.

Thus, this study reveals that the involvement of students in practical learning can strengthen six DLC, that is, (1) Mastering core academic content, (2) Engaging in critical thinking and solving complex problems, (3) Working collaboratively, (4) Communicating effectively, (5) Learning how to learn, and (6) Developing academic mindsets. PBL and SBE are two practical activities that have a very strong impact on DLC. Meanwhile, internship and learning through practice both have a strong impact and tend to have a strong influence on development of DLC (see Table 5 and Figure 3).

Table 5: Deeper learning competencies

\begin{tabular}{|l|l|l|l|l|l|l|l|l|l|l|}
\hline Competencies & \multicolumn{2}{|c|}{ Practice } & \multicolumn{2}{|c|}{ Internship } & \multicolumn{2}{|c|}{ PBL } & \multicolumn{2}{|c|}{ SBE } & \multicolumn{2}{|c|}{ Mean } \\
\hline $\begin{array}{l}\text { Master core } \\
\text { academic } \\
\text { content }\end{array}$ & 5.7 & High & 6.1 & High & 6.7 & $\begin{array}{l}\text { Very } \\
\text { high }\end{array}$ & 6.5 & $\begin{array}{c}\text { Very } \\
\text { high }\end{array}$ & 6.25 & $\begin{array}{c}\text { Very } \\
\text { high }\end{array}$ \\
\hline $\begin{array}{l}\text { Solve } \\
\text { problems } \\
\text { critically }\end{array}$ & 5.3 & High & 5.7 & High & 6.8 & $\begin{array}{c}\text { Very } \\
\text { high }\end{array}$ & 6.6 & $\begin{array}{l}\text { Very } \\
\text { high }\end{array}$ & 6.1 & High \\
\hline $\begin{array}{l}\text { Communicate } \\
\text { effectively }\end{array}$ & 4.8 & $\begin{array}{l}\text { Slightly } \\
\text { high }\end{array}$ & 6.2 & $\begin{array}{l}\text { Very } \\
\text { high }\end{array}$ & 6.85 & $\begin{array}{l}\text { Very } \\
\text { high }\end{array}$ & 6.5 & $\begin{array}{l}\text { Very } \\
\text { high }\end{array}$ & 6.09 & High \\
\hline $\begin{array}{l}\text { Learn how to } \\
\text { learn }\end{array}$ & 4.9 & $\begin{array}{l}\text { Slightly } \\
\text { high }\end{array}$ & 5.5 & High & 6.9 & $\begin{array}{l}\text { Very } \\
\text { high }\end{array}$ & 6.6 & $\begin{array}{l}\text { Very } \\
\text { high }\end{array}$ & 5.98 & High \\
\hline Collaborate & 4.7 & $\begin{array}{l}\text { Slightly } \\
\text { high }\end{array}$ & 5.3 & High & 6.9 & $\begin{array}{l}\text { Very } \\
\text { high }\end{array}$ & 6.7 & $\begin{array}{l}\text { Very } \\
\text { high }\end{array}$ & 6.15 & $\begin{array}{l}\text { Very } \\
\text { high }\end{array}$ \\
\hline $\begin{array}{l}\text { Academic } \\
\text { mindset }\end{array}$ & 4.6 & $\begin{array}{l}\text { Slightly } \\
\text { high }\end{array}$ & 5.9 & High & 6.6 & $\begin{array}{l}\text { Very } \\
\text { high }\end{array}$ & 6.4 & $\begin{array}{l}\text { Very } \\
\text { high }\end{array}$ & 5.88 & High \\
\hline Average & 5 & $\begin{array}{l}\text { Slightly } \\
\text { high }\end{array}$ & 5.95 & High & 6.79 & $\begin{array}{l}\text { Very } \\
\text { high }\end{array}$ & 6.55 & $\begin{array}{l}\text { Very } \\
\text { high }\end{array}$ & 6.07 & High \\
\hline
\end{tabular}




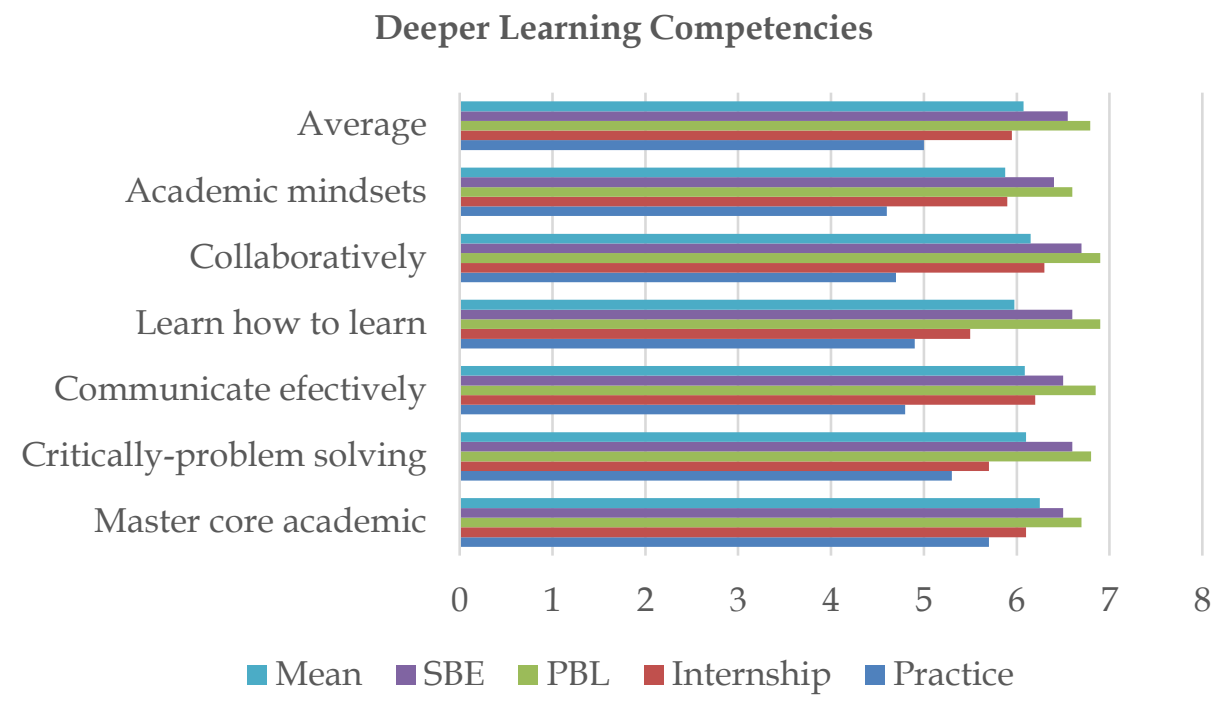

Figure 3: Deeper learning competencies based on practical learning model

\section{Discussion}

PBL is a learning activity that has a strong impact on strengthening student involvement in learning. Its indicator is student involvement in developing independent learning, participation and interest, and emotional involvement. This study reveals that practical learning can foster student learning activities. The most effective practical learning activities for strengthening students' learning were as follows: PBL, SBE, internship, and learning through practice.

The results of this research are in line with previous research. Most other studies show that the intensity of student involvement in learning is the main factor that determines students' success during their study period (Walsh \& Sattes, 2017; Wang \& Fredricks, 2014; Axelson \& Flick, 2010). Likewise, the research of Prince (2004) and Freeman et al. (2014) reveals that student activity in learning is decisive for the success of their studies. It means that teachers must create conditions and learning activities that engage students actively in learning (Carr et al., 2015; Gray \& DiLoreto,2016).

Active learning is a learning activity that involves students in doing something and thinking about what they are doing. The four practical learning activities studied in this research are basically the implementation of active learning. When engaged in practical learning, students do not just listen and remember what the teacher explains. Instead, they are also involved in observing, identifying, recording, analyzing in process, categorizing, testing, evaluating, and developing what has been done. In other words, the involvement of students in practical learning can foster deep involvement in practical learning activities that will encourage students to develop higher order thinking skills.

The need to implement practical learning in schools can be seen from its impact, as explained in the book, Practice Makes Perfect: The Importance of Practical Learning 
(Kehoe, 2007). The results of this study are in line with previous research that found various positive impacts if students are intensively involved in practical learning. One example is the research conducted by Claxton et al. (2010), which identifies at least four thinking habits that students are expected to develop after participating in practice-based learning, namely, (1) The habit of conducting investigations, (2) The habit of experimenting, (3) The habit of imagining, and (4) The habit of rational thinking (in deciding something).

Yazzie-Mintz (2010) and Ferrandez-Berrueco et al. (2016) also reveal various mental attitudes that can be strengthened through practice-based learning, including (1) Intense curiosity (generating a proactive attitude), (2) Strong determination (creating an unyielding attitude, growing the habit of working thoroughly), (3) The ability to use reason (being encouraged to use rational considerations in dealing with problems, optimizing various available resources), (4) The ability to build social relationships, collaboration, and communication (students contribute optimally in solving complex problems), (5) Self-reflection skills (students evaluate themselves and develop thinking to make improvements), (6) Exhibiting wisdom (students are familiarized to behave in harmony with the demands of the social environment).

Thus, student involvement in practical learning can strengthen students' intelligence for dealing with the real world (real-world intelligence). Practical learning will encourage students to optimize their thinking and physical abilities to engage in learning. Practical learning can encourage students to behave productively by, for instance, (1) Searching (students are accustomed to finding something, not just seeing), (2) Listening (students are accustomed to listening to other people's opinions, capturing important messages from the information they receive, and respecting anyone), (3) Sniffing (not only smelling - students hone their skills in photographing a problem, so they can identify the problem they face), (4) Enjoying (not only tasting - students involve their minds, all members of the group), (5) Feeling (not only touch - students feel and appreciate the problems face, so they can find unique, creative, and innovative solutions).

DLC is a set of knowledge and skills that must be mastered by students as a requirement for entering real life after graduation. To be able to actively participate in community life and face intense competition, students must master DLC. Students must master a set of learning competencies and develop a sharp and deep understanding of the content of knowledge, and must be able to apply it in everyday life (AIR, 2015).

To understand the subject matter deeply, students must be actively involved in learning activities. Deep involvement in learning can provide opportunities to understand better, develop knowledge, and apply the knowledge they have understood, which is a requirement for creating new knowledge. Doing so will strengthen students' independence in the learning process. Students will be accustomed to assessing and determining various pieces of knowledge that are considered principal, functional, and interrelated. Well mastered deep learning skills can strengthen students' readiness to enter real life. 
The results of this study prove that the activeness of students in practical learning has a positive impact on the growth of DLC. The effectiveness of practical learning is strongly influenced by the extent to which students are actively involved in learning. As stated by Bonwell and Eison (1991), active learning, as the main characteristic of practical learning, must involve students in doing something and thinking about what they are doing.

Likewise, a study conducted by Prince (2004) states that a practical learning approach that promotes active learning is more focused on developing student skills than transmitting information and requires students to do something, like reading, discussing, or writing, which requires higher order thinking. Practical learning emphasizes students' exploration of their attitudes and values. Meanwhile, studies conducted by Carr et al. (2015) and Freeman et al. (2014) reveal that active learning strengthens students' ability to construct knowledge, and makes them accustomed to working in teams on projects, to make presentations, ask questions, work with people outside their community, and contribute to discussions. In short, practical learning that emphasizes student learning activities can strengthen DLC.

\section{Conclusion}

This study concludes that the implementation of four practical activities - learning through practice, internship, PBL, and SBE - fosters student learning involvement, which can be identified through five aspects, namely, participation in learning, the seriousness of students in carrying out the task, students' attention to and interest in practical learning, the emotions and feelings students express when carrying out practical learning, and students' independence in learning. The implementation of four practical learning activities fosters various skills and positive attitudes, namely, academic skills, practical skills, learning how to learn, work attitudes, career orientation, work readiness, collaboration, and communication.

The involvement of students in four practical learning activities and the various impacts of these activities have been proven to foster DLC, which are a set of competencies needed by students to live life in the real world after they graduate from school. These competencies are mastering core academic content, critical thinking and complex problem-solving, working collaboratively, communicating effectively, being an autonomous learner or learning how to learn, and having an academic mindset. To strengthen students' DLC, learning activities must combine theory and practice into a series of learning activities of which the elements cannot be separated.

\section{References}

AIR (2015, August). Deeper learning improving students' outcomes for college, career, and civic life. $\quad$ https://www.air.org/sites/default/files/downloads/report/DeeperLearning-EPC-Brief-August-2015.pdf

Ali, M. M., \& Hasan, N. (2018). Defining concepts of student engagement and factors contributing to their engagement in schools. Creative Education, 9, 2161-2170. https://doi.org/10.4236/ce.2018.914157 
Alliance for Excellent Education (2011, May). A time for deeper learning: Preparing students for a changing world. Policy Brief. https://all4ed.org/wpcontent/uploads/2013/06/DeeperLearning.pdf

Arikunto, S. (2019). Prosedur Penelitian Suatu Pendekatan Praktik [Research procedure, A practical approach]. Rineka Cipta.

Audas, R., \& Willms, J. D. (2001, February). Engagement and dropping out of school: A lifecourse perspective. Working Paper Series W-01-1-10E. Human Resources and Social Development Canada. https://publications.gc.ca/collections/Collection/MP3228-01-1-10E.pdf

Axelson, R. D., \& Flick, A. (2010). Defining student engagement. Change: The Magazine of Higher Learning, 43(1), 38-43. https:/ / doi.org/10.1080/0 0091383.2011.533096

Billet, S. (2013). Learning through practice: beyond informal and towards a framework for learning through practice In Revisiting global trends in TVET: Reflection on theory and practice (pp. 123-163). UNESCO-UNEVOC International Centre for Technical and Vocational Education and Training.

Bonwell, C. C., \& Eison, J.A. (1991). Active learning: creating excitement in the classroom. ASH\#-ERIC Higher Education Report No. 1. George Washington University, School of Education and Human Development.

Briggs, A. (2015, February). Ten ways to overcome barriers to student engagement online. Online Learning Consortium. http://onlinelearningconsortium.org/news_item/tenways-overcome-barriersstudent-engagement-online/

Carr, R., Palmer, S., \& Hagel, P. (2015). Active learning: the importance of developing a comprehensive measure. Active Learning in Higher Education, 16, 173-186. https://doi.org/10.1177/1469787415589529

Clapton, G., \& Cree, V. (2004). Learning for effective and ethical practice. Literature review. Scottish Institute for Excellence in Social Work Education. http://www.iriss.org.uk/files/LEEP11LitRev.pdf

Claxton, G., Lucas, B., \& Webster, R. (2010). Bodies of knowledge, how new scientific understanding can help practical education. Edge Foundation.

Commission on Adult Vocational Teaching and Learning. (2013). It's about work: Excellent adult vocational teaching and learning. Learning and Skills Improvement Service. https:/ / repository.excellencegateway.org.uk/CAVTL-Its-about-workReport.pdf

Deissinger, T., \& Hellwig, S. (2005). Apprenticeships in Germany: modernising the dual system. Education and Training, 47(4/5), 312-324. https://doi.org/10.1108/00400910510601896

Eraut, M. (2004). Informal learning in the workplace. In H. Rainbird, A. Fuller \& A. Munro (Eds.), Workplace learning in context. Routledge. https://doi.org/10.1080/158037042000225245

Ferrandez-Berrueco, R. M., Kekale, T., \& Devins, D. (2016). A framework for work-based learning: basic pillars and the interactions between them. Journal of Higher Education Skills and Work-Based Learning, 6(1), 35-54. https:// doi.org/10.1108/HESWBL-06-2014-0026

Fredricks, J. A., Blumenfeld, P. C., \& Paris, A. H. (2004). School engagement: Potential of the concept, state of the evidence. Review of Educational Research, 74(1), 59-109. https://doi.org/10.3102/00346543074001059

Freeman, S., Eddy, S. L., McDonough, M., Smith, M. K., Okoroafor, N., Jordt, H., \& Wenderoth, M. P., (2014). Active learning increases student performance in science, engineering, and mathematics. Proceedings of the National Academy of Sciences USA 111, 8410-8415. https:/ / doi.org/10.1073/pnas.1319030111 
Gamache, P., \& Knab, J. (2018). School-based enterprise development: Planning, implementing and evaluating. Florida Department of Education K-12 Education Bureau of Exceptional Education and Student Services. http://project10.info/Documents/SBE_Manual_with_Final_WM_Edits_Include d_7.13.18_1.pdf

Gray, J.A., \& DiLoreto, M. (2016), The effects of student engagement, student satisfaction, and perceived learning in online learning environments. NCPEA International Journal of Educational Leadership Preparation, 11(1). https://files.eric.ed.gov/fulltext/EJ1103654.pdf

Gugerty, J., Foley, C., Frank, A., \& Olson, C. (2008). Developing and operating school based-enterprises that empower special education students to learn and connect classroom, community, and career-related skills. The Journal for Vocational Special Needs Education, 31, 19-56. https://silo.tips/download/the-journal-forvocational-special-needs-education-19

Hadam, S., Rahayu, N., \& Ariyadi, A. N. (2017). Strategi Implementasi Revitalisasi SMK (10 Langkah Revitalisasi SMK) [Implementation strategy of vocational high school revitalization (10 steps of revitalization)]. Jakarta: Direktorat Pembinaan Sekolah Menengah Kejuruan, Direktorat Jenderal Pendidikan Dasar dan Menengah, Kementerian Pendidikan dan Kebudayaan.

Hewlett Foundation (2013, April). Deeper learning competencies. https://hewlett.org/wpcontent/uploads/2016/08/Deeper_Learning_Defined_April_2013.pdf

Hung, V. H. K., Keppel, M., \& Jong, M. S. Y. (2004). Learners as producers: Using PBL to enhance meaningful learning through digital video production. http://repository.ied.edu.hk/dspace/handle/2260.2/

Kehoe, D. (Ed.). (2007). Practice makes perfect: The importance of practical learning. The Social Market Foundation. https://www.smf.co.uk/wpcontent/uploads/2007/03/Publication-Practice-Makes-Perfect-The-Importanceof-Practical-Learning.pdf

Leonard, S. H. (2008). Measuring cognitive and psychological engagement in middle school students (Doctoral thesis). University of South Dakota. http://search.proquest.com.www.ezplib.ukm.my/docview/304464018/fulltext PDF/1377 DCE32E07B5D9A43/1?accountid=41453

MacFarlane, J., Aladjem, D., \& Russel, C. A. (2017, May). Instructional practices for deeper learning: Lessons for educators. Policy Studies Associates. https://asiasociety.org/files/instructional-practices-for-deeper-learninglessons-for-educators-may-2017-report.pdf

Martinez, M. R., McGrath, D. R., \& Foster, E. (2016). How deeper learning can create a new vision for teaching. National Commission on Teaching and America's Future. http://www.monicarmartinez.com/wp-content/uploads/2019/11/NCTAFHow-Deeper-Learning-Can-Create-a-New-Vision-for-Teaching.pdf

Narbuko, C., \& Achmadi, A. (2015). Metodologi Penelitian [Research method]. PT Bumi Aksara.

Pellegrino, J. W., \& Hilton, M. L. (Eds.) (2012). Education for life and work: Developing transferable knowledge and skills in the 21st century. Consensus Study Report. The National Academies Press. https://doi.org/10.17226/13398

Prianto, A. (2016). Students' engagement in scientific approach based learning and its effect on students' readiness to compete. IOSR Journal of Research \& Method in Education (IOSR-JRME), 6(1), 1-12. https://doi.org/10.9790/7388-06110112

Prince, M. (2004). Does active learning work? A review of the research. Journal of Engineering Education, 93, 223-231. https://doi.org/10.1002/j.21689830.2004.tb00809.x 
Republic of Indonesia. (2003). Undang Undang Republik Indonesia Nomor 13 Tahun 2013 Tentang Ketenagakerjaan [Law No. 13 of 2003 concerning manpower]. https:// kemenperin.go.id/kompetensi/UU_13_2003.pdf

Roesman, R. (1988). Ketrampilan Psikomotorik [Psychomotor skills]. Depdikbud.

Salleh, A. M., Desa, M. M., \& Tuit, R. M. (2013). The relationship between the learning ecology system and students' engagement: A case study in Selangor. Asian Social Science, 9, 110-117. https:// doi.org/10.5539/ass.v9n12p110

Scheaffer, R. L., Mendenhall, W., \& Ott, L. (1995). Elementary survey sampling. PWS-KENT Publ. Co.

Smith, D. C., Ito, A., Gruenewald, J., \& Yeh, H. L. (2010). Promoting school engagement: attitudes toward school among American and Japanese youth. Journal of School Violence, 9, 392-406. https:/ / doi.org/10.1080/15388220.2010.509308

Stern, D., Stone, J., Hopkins, C., McMillion, M., \& Crain, R. (1994). School-based enterprise: Productive learning in American high schools. Jossey-Bass Publishers.

STORIES Consortium (2017). Stories of Tomorrow - Learners visions on the future of space exploration. Collaborative Project in European Union's 2020 Research and Innovation

Programme. https://ec.europa.eu/research/participants/documents/downloadPublic?docu mentIds=080166e5b2047149\&appId=PPGMS

Sugiyono. (2018). Metode Penelitian Kuantitatif, Kualitatif, dan RED [Quantitative, qualitative, and $R$ \& $D$ research methods]. Alfabeta.

Sukmadinata, N. S. (2017). Metode Penelitian Pendidikan [Educational research methods]. PT Remaja Rosdakarya.

Sumarni, W. (2015, March). The strengths and weaknesses of the implementation of project based learning: A review. International Journal of Science and Research, 4(3), 478-484. https://www.ijsr.net/archive/v4i3/SUB152023.pdf

Trilling, B. (2010). Defining competence in deeper learning (draft report to the Hewlett Foundation). Hewlett Foundation.

Vander Ark, T. \& Schneider, C. (2013, December). Deeper learning for every student every day. GetingSmart.com. https://www.gettingsmart.com/wpcontent/uploads/2013/12/DLForEveryStudent_FINAL.pdf

Walker, H. M., \& Shinn, M. R. (2002). Structuring school-based interventions to achieve integrated primary, secondary, and tertiary prevention goals for safe and effective schools. In M. Shinn, H. Walker, \& G. Stoner (Eds.), Interventions for academic and behavior problems II: Preventive and remedial approaches. National Association of School Psychologists.

Walsh, J. A., \& Sattes, B. D. (2017). Quality questioning: Research-based practice to engage every learner, 2nd ed. Corwin.

Wang, M. T., \& Fredricks, J. A. (2014). The reciprocal links between school engagement, youth problem behaviors, and school dropout during adolescence. Child Development, 85(2), 722-737. https:// doi.org/10.1111/cdev.12138

Wren, J., \& Wren, B. (2009). Enhancing learning by integrating theory and practice. International Journal of Teaching and Learning in Higher Education, 21(2), 258-265. https://files.eric.ed.gov/fulltext/EJ899313.pdf

Yazzie-Mintz, E. (2010). Charting the path from engagement to achievement: A report on the 2009 High School Survey of Student Engagement. Center for Evaluation \& Education Policy.

http://ijlter.org/index.php/ijlter 


\section{Appendix}

\section{QUESTIONNAIRE ON STUDENT INVOLVEMENT IN PRACTICAL LEARNING, THE IMPACT OF PRACTICAL LEARNING, AND DEEPER LEARNING COMPETENCIES}

Dear teachers,

Please use this questionnaire to assess students regarding student involvement' in practical learning, the impact of student involvement in practical learning, and deeper learning competencies. Please conduct an assessment after the students have finished carrying out 4 practical learning activities, namely: (1) learning through practice, (2) Internship, (3) Project-based learning, and (4) School-based enterprise. This questionnaire uses a scale of $1-7(1=$ very low; $2=$ low; $3=$ slightly low; $4=$ moderate; $5=$ slightly high; $6=$ high; $7=$ very high).

Thank you for your cooperation.

I. Practical learning that students participate in (Please choose one of them):
a. Learning through practice
b. Internship
c. Project-based learning
d. School-based enterprise

II. Student identity
a. Initial respondent :
b. Grade
c. School name
d. Academic year
e. Semester

III. Questionnaire statement

Student involvement in practical learning

\begin{tabular}{|c|c|c|c|c|c|c|c|c|}
\hline \multirow{2}{*}{ Item } & \multirow{2}{*}{ Questionnaire statement } & \multicolumn{7}{|c|}{ Your Rating } \\
\hline & & 1 & 2 & 3 & 4 & 5 & 6 & 7 \\
\hline 1 & $\begin{array}{l}\text { Students actively participate in practical } \\
\text { learning }\end{array}$ & & & & & & & \\
\hline 2 & $\begin{array}{l}\text { Students carry out practical learning tasks } \\
\text { seriously }\end{array}$ & & & & & & & \\
\hline 3 & $\begin{array}{l}\text { Students show high interest in practical } \\
\text { learning }\end{array}$ & & & & & & & \\
\hline 4 & $\begin{array}{l}\text { Students show a happy and enthusiastic } \\
\text { attitude when carrying out practical learning }\end{array}$ & & & & & & & \\
\hline 5 & $\begin{array}{l}\text { Students show independence to learn more } \\
\text { what has been learned in practical learning }\end{array}$ & & & & & & & \\
\hline
\end{tabular}


Impact of practical learning

\begin{tabular}{|c|c|c|c|c|c|c|c|c|}
\hline \multirow{2}{*}{ Item } & \multirow{2}{*}{ Questionnaire statement } & \multicolumn{7}{|c|}{ Your Rating } \\
\hline & & 1 & 2 & 3 & 4 & 5 & 6 & 7 \\
\hline 1 & $\begin{array}{l}\text { Students are able to think creatively, } \\
\text { innovatively, and analytically to solve } \\
\text { complex problems }\end{array}$ & & & & & & & \\
\hline 2 & $\begin{array}{l}\text { Students are able to apply theory to carry out } \\
\text { certain tasks }\end{array}$ & & & & & & & \\
\hline 3 & $\begin{array}{l}\text { Students are able to direct themselves to } \\
\text { explore the subject matter that has been } \\
\text { studied at school }\end{array}$ & & & & & & & \\
\hline 4 & $\begin{array}{l}\text { Students show positive work behavior and } \\
\text { attitudes }\end{array}$ & & & & & & & \\
\hline 5 & $\begin{array}{l}\text { Students understand about the career they } \\
\text { will pursue after graduation }\end{array}$ & & & & & & & \\
\hline 6 & Students demonstrate work readiness & & & & & & & \\
\hline 7 & Students are able to work in teams & & & & & & & \\
\hline 8 & $\begin{array}{l}\text { Students are able to communicate well, both } \\
\text { orally and written, on various activities that } \\
\text { have been carried out in practical learning }\end{array}$ & & & & & & & \\
\hline
\end{tabular}

Deeper learning competencies

\begin{tabular}{|c|l|c|c|c|c|c|c|c|}
\hline \multirow{2}{*}{ Item } & Questionnaire statement & \multicolumn{5}{|c|}{ Your Rating } \\
\hline 1 & $\begin{array}{l}\text { Students are able to apply facts, processes, } \\
\text { and theories to real-world situations }\end{array}$ & & & & & & \\
\hline 2 & $\begin{array}{l}\text { Students are able to apply tools and } \\
\text { techniques for certain activities to collect the } \\
\text { necessary data and information }\end{array}$ & & & & & & \\
\hline 3 & $\begin{array}{l}\text { Students are able to collaborate with others to } \\
\text { complete assignments and solve problems } \\
\text { successfully }\end{array}$ & & & & & & & \\
\hline 4 & $\begin{array}{l}\text { Students are able to communicate complex } \\
\text { concepts to others in both written and oral } \\
\text { presentations }\end{array}$ & & & & & & & \\
\hline 5 & $\begin{array}{l}\text { Students are regularly able to reflect on their } \\
\text { learning experiences and apply their } \\
\text { understanding to subsequent situations }\end{array}$ & & & & & & & \\
\hline 6 & $\begin{array}{l}\text { Students readily involve in developing } \\
\text { meaning and constructing understanding } \\
\text { through interaction with peers }\end{array}$ & & & & & & \\
\hline
\end{tabular}

